\title{
Microbiological evaluation of the meat from young collared peccaries (Pecari tajacu
}

\section{Linnaeus, 1758)}

\author{
Avaliação microbiológica da carne de catetos jovens (Pecari tajacu Linnaeus, 1758) \\ Evaluación microbiológica de la carne de pecaríes de collar jóvenes (Pecari tajacu Linnaeus, 1758)
}

Joyce Galvão de Souza

ORCID: https://orcid.org/0000-0001-5492-6317 Universidade Federal de Campina Grande, Brazil E-mail: joycegalvaosouza@gmail.com

Aline Antas Cordeiro Cavalcanti ORCID: https://orcid.org/0000-0002-0904-1517 Universidade Federal de Campina Grande, Brazil E-mail: aline.antas@gmail.com

Brunna Muniz Rodrigues Falcão ORCID: https://orcid.org/0000-0002-4781-8470 Universidade Federal de Campina Grande, Brazil E-mail: brunnamrfalcao@ hotmail.com

Iara Nunes de Siqueira

ORCID: https://orcid.org/0000-0001-9972-0064

Universidade Federal de Campina Grande, Brazil E-mail: iaraepedro@bol.com.br

Artur da Nóbrega Carreiro

ORCID: https://orcid.org/0000-0002-2131-7432

Universidade Federal de Campina Grande, Brazil E-mail: arturpets1992@gmail.com

Moana Barbosa dos Santos Figuerêdo

ORCID: https://orcid.org/0000-0001-5102-5089

Universidade Federal de Campina Grande, Brazil E-mail: moana_figueredo@hotmail.com

Luan Nascimento Batista

ORCID: https://orcid.org/0000-0001-9684-5865 Universidade Federal de Campina Grande, Brazil E-mail: luan.nacimento@hotmail.com

Filipe Jordão Pereira de Medeiros ORCID: https://orcid.org/0000-0003-3099-5929 Universidade Federal de Campina Grande, Brazil E-mail: filipejordaomedvet@gmail.com

José Emanuel de Souza Sales

ORCID: https://orcid.org/0000-0002-1317-0856 Universidade Federal de Campina Grande, Brazil E-mail: emanuel_sales1995@gmail.com

Moacir Franco de Oliveira

ORCID: https://orcid.org/0000-0002-6269-0823 Universidade Federal Rural do Semi-Árido, Brazil E-mail: moacir@ufersa.edu.br

Nara Geanne de Araújo Medeiros ORCID: https://orcid.org/0000-0002-6142-6668 Universidade Federal de Campina Grande, Brazil E-mail: nara210573@gmail.com

Danilo José Ayres de Menezes ORCID: https://orcid.org/0000-0001-6089-3283 Universidade Federal do Rio Grande do Norte, Brazil E-mail:mdanayres@gmail.com

\begin{abstract}
The increased demand for meat from wild animals for human consumption, as an alternative protein source, brings with it the need for research that demonstrates the quality of such product. The technical information about the meat from collared peccaries still needs studies and aiming to collaborate with the already existing knowledge, this research had as its objective to provide subsidies for evaluation of the sanitary quality of the meat from collared peccaries.
\end{abstract}


Twelve animals were used, six males and six females, aged four to five months, from the breeding stock of the Federal Rural University of the Semi-Arid and, after euthanasia by a slaughter technique used in goats, the meat samples were collected through sterile swabs at the locations of the hind leg, loin, belly and axilla of each animal, totaling 48 samples. The maximum mesophilic count found was $1.9 \times 10^{3} \mathrm{CFU} / \mathrm{ml}$, the total coliform and thermotolerant coliform counts were below the one determined in the legislation for meat from domestic animals, however, through biochemical tests, the presence of $E$. coli from the biotype 1 and biotype 2 was found, in seven and six samples, respectively. Search results for Salmonella spp. were negative in all samples and, as for Staphylococcus spp., only one sample had the count above the level allowed by law. The contamination load related to the bacteria $E$. coli proved to be high, making 13 samples unfit for consumption. Regarding the other data, the meat from young collared peccaries showed a low contamination load.

Keywords: Bacterium, Food safety; Tayassuidae.

\begin{abstract}
Resumo
O aumento da procura por carne de animais silvestres para o consume humano como uma fonte de proteína alternativa traz consigo a necessidade de pesquisas que demonstrem a qualidade dos produtos. As informações técnicas sobre a carne de cateto ainda carecem de estudos e, visando colaborar com os conhecimentos já existentes, objetivou-se nesta pesquisa fornecer subsídios para a avaliação da qualidade sanitária da carne de catetos. Foram utilizados 12 animais, seis machos e seis fêmeas, com idade entre quatro e cinco meses, do plantel da Universidade Federal Rural do SemiÁrido e, após eutanásia por técnicas de abate para caprinos, as amostras de carne foram coletadas por meio de swabs estéreis nos pontos de pernil, lombo, barriga e axila de cada animal, totalizando 48 amostras. A contagem máxima de mesófilos encontrada foi de $1,9 \times 10^{3} \mathrm{UFC} / \mathrm{ml}$, as contagens de coliformes totais e coliformes termotolerantes ficaram abaixo do determinado na legislação para animais domésticos, porém, por meio de testes bioquímicos foi constatada a presença de Escherichia coli de biotipo 1 e biotipo 2 em sete e seis amostras, respectivamente. Resultados da pesquisa para Salmonella spp. foram negativos em todas as amostras e, quanto a Staphylococcus spp., apenas uma amostra apresentou contagem acima do permitido por lei. A carga de contaminação relacionada à bacteria $E$. coli se mostrou elevada, tornando 13 amostras impróprias para consumo. Em relação aos demais dados, a carne de catetos jovens apresentou baixa carga de contaminação.
\end{abstract}

Palavras-chave: Bactérias; Segurança alimentar; Tayassuidae.

\title{
Resumen
}

El aumento de la demanda de carne de animales silvestres para consumo humano como fuente alternativa de proteínas trae consigo la necesidad de investigaciones que demuestren la calidad de los productos. La información técnica sobre la carne de pollo aún debe ser estudiada y, con el objetivo de colaborar con el conocimiento existente, esta investigación tuvo como objetivo otorgar subsidios para la evaluación de la calidad sanitaria de la carne de pollo. Se utilizaron doce animales, seis machos y seis hembras, de entre cuatro y cinco meses, de la brigada de la Universidad Federal Rural del Semiárido y, tras la eutanasia mediante técnicas de sacrificio de cabras, se recogieron las muestras de carne mediante hisopos. estéril en las puntas de la pierna, el lomo, el vientre y el azila de cada animal, totalizando 48 muestras. El conteo máximo de mesófilos encontrado fue de 1.9 x 103 UFC / ml, los conteos de coliformes totales y coliformes termotolerantes estuvieron por debajo de lo determinado en la legislación para animales domésticos, sin embargo, mediante pruebas bioquímicas la presencia de Escherichia coli de biotipo 1 y biotipo 2 en siete y seis muestras, respectivamente. Resultados de la búsqueda de Salmonella spp. fueron negativas en todas las muestras y, en cuanto a Staphylococcus spp., solo una muestra tuvo un recuento superior al permitido por la ley. La carga de contaminación relacionada con la bacteria E. coli resultó ser alta, lo que hizo que 13 muestras no fueran aptas para el consumo. En relación al resto de datos, la carne de recolectores jóvenes presentó una carga contaminante baja.

Palabras clave: Bacterias; Seguridad alimentaria; Tayassuidae.

\section{Introduction}

The consumption of meat from certain species of wild animals with zootechnical potential may offer advantages for its conservation by establishing management plans that use animals kept in their natural environments, but with the intention of maintaining surpluses that are destined for slaughter and consumption, in addition, this alternative source of animal protein is of interest to many rural producers, however, studies on its viability are scarce (Nogueira \& Nogueira, 2000).

The risk originating in meat from wild animals of being potential sources of contamination for the development of diseases still consists in a limiting factor for its consumption, despite the nutritional quality (Sarkis, 2002). Animal health is the main basis for supporting the development of any animal production system. Hygiene and preventive management make 
production economically viable (Domingues, 2008), because one of the problems that most affects the population worldwide is the transmission of diseases through food (Martins, et al., 2008).

The chain of production for food has been adapting to the necessity of meeting the quality and price requirements demanded by consumers of different economic levels, cultures and social habits. Being an important point to consider that, with the advances of the last decades with regard to the speed of transport, a greater number of people are exposed to the same product and consequently to the same danger that it may carry (Spolaore, 2007). Approximately 600 million new cases of diseases caused by contaminated food in humans occur every year around the world and lead to 420,000 deaths (World Health Organization [WHO], 2019).

The collared peccary, along with the white-lipped peccary and the capybara, are among the wild animals most hunted for consumption in Latin America (Moreira \& Macdonald, 1997). The Pecari tajacu species has a natural occurring zone, from the southern United States of America to northern Argentina, and it can be found in different habitats that include desert regions and humid or arid tropical forests, being animals that have good resistance to the variation of ambient temperature and humidity, resisting both values below $0^{\circ} \mathrm{C}$ and above $45^{\circ} \mathrm{C}$ and humidity from 6 to $80 \%$ (Furtado, 2014).

Among the foods most involved in toxinfections in humans, are those based on meat and eggs, and among the most important bacterial microorganisms are Salmonella spp. and Escherichia coli (Oliveira, et al., 2010).

The classification of E. coli includes it both in the group of total coliforms and thermotolerant coliforms (Silva et al., 2017). Bacteria of the genus Salmonella are frequently found in the intestinal tract of animals, both endothermic and exothermic ones, being an important cause of infections in humans and animals (Quintiliano, et al., 2008). These bacteria represent an important source of contamination in animal products that can cause human salmonellosis (Parry, 2003).

The disease caused by Staphylococcus aureus is classified as "of moderate danger, usually of short duration and without threat of death or sequelae, with self-limiting symptoms, but causing severe discomfort", included in risk group III according to the International Commission on Microbiological Specifications for Foods [ICMSF] (2002), with some of its strains capable of producing toxins that are involved in several outbreaks of toxinfections in humans (Lamaita, et al., 2005).

In this context, this research aimed to investigate the natural presence of mesophiles, total coliforms, thermotolerant coliforms, Escherichia coli, Salmonella spp. and Staphylococcus aureus on the surface of the carcasses from young collared peccaries at the locations of the hind leg (ham), loin, belly and axilla, in order to obtain information that may collaborate with zootechnical data about the species.

\section{Methodology}

The project was submitted to the Biodiversity Authorization and Information System (SISBIO) under number 362635 and the Ethics Committee for Animal Use of the Federal University of Rio Grande do Norte under number 039.032/2017. The material collection was carried out at the Center for Multiplication of Wild Animals (CEMAS) from the Federal Rural University of the Semi-arid (UFERSA), located in the city of Mossoró, in the state of Rio Grande do Norte. Sample analyzes were performed at the Meat Technology and Inspection Laboratory from the Federal University of Campina Grande (UFCG), located in the city of Patos, in the state of Paraíba, Brazil.

Twelve animals aged between four and five months were used, six males and six females. The animals were slaughtered in an experimental slaughterhouse, following the precepts of humane slaughter with previous stunning using a captive bolt pistol for goats followed by the bleeding, skinning and evisceration stages, and collections with sterile swabs were performed on the surfaces of the hot carcasses, preceding the stage of their division, in four points with a $10 \mathrm{~cm} \times 10 \mathrm{~cm}$ template. The collection points used were the locations of the hind leg, loin, belly and axilla, according to what is described for 
pigs in the Normative Instruction $\mathrm{n}^{\circ}$ 59, from December 19, 2018, by the Ministry of Agriculture, Livestock and Supply [MAPA] (2018).

Samples were collected using two swabs per collection point, totaling 48 samples, one being transported in $25 \mathrm{ml}$ of $0.1 \%$ Peptone Water and the second in $10 \mathrm{ml}$ of the same solution, which were used for the Salmonella research and for the other bacteria that are object of this study, respectively. The samples were transported according to what was determined by Ministry of Agriculture, Livestock and Supply [MAPA] (2017) and were prepared according to the methodology described by Talor, et al. (2015).

For the research of mesophiles, total coliforms, thermotolerant coliforms and Escherichia coli, methods by the American Public Health Association were followed (APHA) (Kornacki, et al., 2015). The method by the Food and Drug Administration (FDA) (Andrews, Jacobson, \& Hammack, 2016) was used for the isolation and identification of Salmonella, where the Salmonella Shigella Agar was used for differential plating. The biochemical tests of Urease, Indole, Malonate, Citrate and test of Methyl Red and Voges Proskauer were performed according to the method from the same methodology. The search for the bacteria Staphylococcus was performed according to the method by the International Organization for Standardization (ISO 6888-1, 1999).

\section{Results}

In the mesophilic research, the average bacterial count was of $5.4 \times 10^{2} \mathrm{CFU} / \mathrm{ml}$ and the highest individual value found was of $1.9 \times 10^{3} \mathrm{CFU} / \mathrm{ml}$ in three samples. The mean count value for total coliforms was of $9.8 \times 10^{1} \mathrm{CFU} / \mathrm{ml}$ and for thermotolerant coliforms $1.0 \times 10^{2} \mathrm{CFU} / \mathrm{ml}$.

In the research to verify the presence of E. coli, in the 48 samples, seven were found positive for biotype 1, in which the indole test was positive, and six samples of biotype 2 in which the indole test was negative for biochemical tests, the samples were obtained from different collection points (axilla, belly and hind leg) and belonged to two different animals.

The arithmetic mean count of colonies with characteristics of the Staphylococcus genus was of $1.9 \times 10^{3} \mathrm{CFU} / \mathrm{ml}$. The presence of the species $S$. aureus was not verified, as all samples were coagulase-negative in the tests used.

Based on bacterial cultures and biochemical tests carried out to detect the presence of bacteria of the genus Salmonella, no positive results were observed in the 48 samples surveyed.

\section{Discussion}

The results obtained were analyzed in accordance to the microbiological standards established for food by the Normative Instruction No. 12 of January 2, 2001, by the National Health Surveillance Agency [ANVISA] (2001), due to the lack of specific parameters for the meat from collared peccaries.

The count, called Standard Plate Count or Total Aerobic Mesophilic Count on plates, provides the researcher with general data regarding the quality of the analyzed sample, providing information on hygiene during its collection and processing, but without identifying the different types of bacteria (Salfinger \& Tortorello, 2015). There are no limit values in the current legislation for the mesophilic count in raw meat of wild animals

The highest individual mesophilic count in the analyzed samples was lower than that found by Sarkis (2002) for one of the samples from collared peccary analyzed, that was $1.5 \times 10^{6} \mathrm{CFU} / \mathrm{g}$, and, Dias, et al. (2012) found high values regarding mesophiles in the meat from captive-bred collared peccaries, collected after slaughter in pig slaughterhouses in the metropolitan region of Belém, in the State of Pará, with $100 \%$ of the samples contaminated with a high bacterial count, making them unsuitable for consumption. The obtaining of the samples by these authors occurred through the purchase in commercial 
establishments, whereas in the present research, the samples were obtained shortly after the slaughter and from animals bred in a controlled environment, thus demonstrating a lower risk for the consumer.

The 48 samples from the coliform survey were within the limit determined by ANVISA (2001). These results corroborate with values observed by Sarkis (2002) for samples from collared peccaries, wild boars and capybaras, and, according to the same author, the variation found for the contamination of their samples may have been influenced by factors such as animal handling, means used for slaughter and the environment in which it occurred, by the way the meat was transported and the way it was stored.

In the research carried out by Dias, et al. (2012), $68.7 \%$ of the meat samples from the collared peccaries showed values for total and thermotolerant coliforms above what is allowed by the legislation. The presence of representatives of the group of total coliforms in large numbers may be an indicator that the cleaning and disinfection processes were not effective; the ideal conditions of time and temperature during production were not respected; food preservation was inadequate or contamination was already present in the raw material (Franco, et al., 2005), which demonstrates that the conditions for breeding and slaughtering the animals in this study were satisfactory for obtaining meat from collared peccaries within the legal parameters required for it.

The resolution RDC $\mathrm{n}^{\circ} 12$ (ANVISA, 2001) does not require the isolation of $E$. coli in meat samples, only the count of thermotolerant coliforms, the group in which this bacterium is inserted. As this count was below the established standard, the 48 samples were suitable for consumption, despite the presence of $E$. coli in the meat of two animals. This fact puts the health of the consumer at risk since this microorganism may cause severe cases of toxinfection depending on the strain involved, as shown by data from institutions that work with diseases transmitted through food. It is necessary to reformulate the rules for raw meat, including the need for absence of E. coli as a quality parameter. In a review of several studies carried out with research on pathogens in wild animals, Moraes and Timm (2020) observed that wild animals can prove to be important reservoirs of several pathogens that can affect both human health and the environment.

However, more research is needed to determine whether it originates from the animals themselves or from steps in handling and slaughter that must be improved, as the intestinal tract of warm-blooded animals is the natural habitat of $E$. coli, however, contamination of food with this bacterium can also occur through non-fecal sources, such as environmental reservoirs (Kornacki, et al., 2015). Operational failures during the processing of bovine carcasses are associated with fecal contamination of their surface by E. coli, and the study of this contaminant in the meat industry is of great importance (Tergney \& Bolton, 2006).

In pork, the contamination by $E$. coli can occur in several points along the way from breeding to the slaughter, this bacterium is of great importance in the hygienic-sanitary point of view and in the public health one because it is a possible indicator of fecal contamination (Franco, et al., 2005). Confirmation of the presence of E. coli in meat intended for consumption makes it unsuitable for this purpose, even when in small quantities due to the risk of gastroenteritis outbreaks, as some strains of this bacterium have the capacity to be enterotoxigenic (Silva, et al., 2017). In the same way that E. coli represents a potential danger for beef and pork, it is also a biological hazard for the meat from the collared peccary.

In the survey of bacteria from the Staphylococcus genus, only one sample (2.08\%) had a count above that allowed by legislation, with a value of $5.5 \times 10^{4} \mathrm{CFU} / \mathrm{ml}$. The other samples showed values within the range allowed for human consumption. In the work carried out by Sarkis (2002), two samples of meat from collared peccaries (22\%) had a higher Staphylococcus count than that established in the resolution RDC $\mathrm{n}^{\circ} 12$ by ANVISA (2001). In the research carried out by Dias, et al. (2012), all samples of meat from collared peccaries showed negative results for the research of coagulase-positive staphylococci. 
The research for Staphylococcus aureus in foods is usually done with the objective of identifying whether the studied food is a source of this bacterium, if the processes through which the food passes in industries are potential sources of contamination or to confirm the involvement of this pathogen in outbreaks of food poisoning (Silva, et al., 2017), thus, the absence of the bacteria Staphylococcus in 47 samples used in this study indicates that the collared peccaries were not a natural habitat of this microorganism and that the management practices in the breeding and slaughter methods were suitable for obtaining meat with a good microbiological standard.

The negative result for the presence of Salmonella in the researched samples is in accordance with the provisions of the RDC $n^{\circ} 12$ by ANVISA (Brazil, 2001), in which there is no tolerable quantity, the absence being the expected result for meat of good quality. According to Salvatori, et al., (2003), when the presence of Salmonella spp. in a food is confirmed, it is automatically unfit for consumption because the presence of this bacterium is associated with several outbreaks of food toxinfection in humans. And as highlighted by Araújo, et al. (2020), Salmonella proves to be one of the main microorganisms involved in cases of food infections in humans through the consumption of pork and its derivatives.

In the study carried out by Dias, et al. (2012), with meat from collared peccaries raised in captivity and slaughtered in pig slaughterhouses, the presence of Salmonella was detected in $14.5 \%$ of the samples. In the research by Adesiyun, et al., (1998), the presence of Salmonella was detected in 2 out of the 5 samples of outdoor-bred collared peccaries, in stool samples and rectal swabs.

In the research carried out by Sarkis (2002), the presence of Salmonella was detected in 22\% of his samples of meat from collared peccaries, making them unfit for consumption. However, these meats were obtained in shops, and the processes of breeding and slaughter of the animals were not supervised and the same author also emphasizes that some factors related to the instruments used during slaughter, the poor hygiene of the handlers, the presence of animals such as rodents and insects or even to the technique used for evisceration, may act as a source of contamination of this bacteria, the latter being aggravated by the lack of legislation that regulates the way the slaughter must be performed., the results of the present research do not corroborate those of Sarkis (2002), but it must be considered that the animals were raised in a controlled environment, with adequate handling and slaughter.

The environmental and food management to which bearing this in mind the animal is subjected during its breeding for slaughter directly affects the microbiological and sensory qualities of the final product because they influence the health and (Sarkis, 2002) and, the types of microorganisms found naturally in the gastrointestinal tract, the musculature and skin of wild animals may directly influence the microbiological conditions of the meat obtained for consumption, and there are also the characteristics of the meat itself that can stress load of the animals favor the development of microorganisms (Gill, 2007).

Thus, it is believed that the low superficial contamination of the meat of the young collared peccaries in this study is due to the correct handling. Since the maintenance of ideal hygienic-sanitary conditions in the slaughter environment is one of the essential points so that the final product obtained can be within the parameters established by inspection agencies (Santos, et al., 2021). According to the results obtained by Dias, et al. (2012), the high counts of certain bacteria in their samples from collared peccaries are probably due to poor hygienic conditions at the time of their slaughter.

However, in order to reduce the risk of contamination of the meat during slaughter and thus make better use of it, parameters must be defined for the breeding and slaughter of collared peccaries.

\section{Conclusion}

The study has demonstrated that by applying adequate control measures in the breeding of collared peccaries, as well as good practices in hygiene and in the execution of the slaughter stages of these animals, the meat exhibited a low presence of 
mesophilic bacteria, total coliforms, thermotolerant coliforms and absence of Salmonella; there was only one non-standard sample in the count for Staphylococcus and isolation of Escherichia coli strain in two animals, indicating the need for a parameter stating that there must be the absence of this bacterium to ensure safety of the raw meat consumed by the population.

\section{Acknowledgments}

To the National Council for Scientific and Technological Development - CNPq for the financial contribution through Universal Call 2016, process CNPq 420945/2016-4.

The Coordination for the Improvement of Higher Education Personnel - CAPES - for the granting of scholarships.

\section{References}

Adesiyun, A. A., Seepersadsingh, N., Inder, L., \& Caesar, K. (1998). Some bacterial enteropathogens in wildlife and Racing pigeons from trinidad. Journal of Wildlife Diseases, 34 (1), 73-80. 10.7589/0090-3558-34.1.73

Agência Nacional de Vigilância Sanitária. (2001). Resolução RDC $N^{o}$ 12, DE 02 de janeiro de 2001. http://portal.anvisa.gov.br/resultadoebusca?p_p_id=101\&p_p_lifecycle=0\&p_p_state=maximized\&p_p_mode=vi ew\&p_p_col_id= column1\&p_p_col _count= 1\&_101_struts_action=\%2F asset_publisher\%2Fview_content\&_101_assetEntryId=2855866\&_101_type=document/

Andrews, W. H., Jacobson, A., \& Hammack, T. S. (2016). Salmonella. In: Food and Drug Administration, Bacteriological Analytical Manual Online. Chapter 5. Retrieved Jan 15, 2020, from https://www.fda.gov/food/laboratory-methods-food/bacteriological-analytical-manual-bam

Araújo, D. S., Moura, F. V. P., Luz, L. E., Bezerra, J. B., Carvalho, M. L., Gonçalves, J. N. A., Sousa, W. G. S., \& Miranda, B. L. (2020). Prevalência de Salmonella spp. em produtos de origem suína. Research, Society and Development, 9 (5), e40952454. 10.33448/rsd-v9i5.2454

Dias, H. L. T., Espinheiro, R. F., Lima, A. S., Kahwage, P. R., Albuquerque, N. I., Guimarães, D. A., \& Silva, F.E. R. (2012). Avaliação microbiológica da carne de caititus (Tayassu tajacu) criados em cativeiro na região metropolitana de Belém, Pará, Brasil. Retrieved Dec 13, 2019, from https://www.embrapa.br/busca-de-publicacoes/-/publicacao/1037058/avaliacao-microbiologica-da-carne-de-caititus-tayasse-tajacu-criados-em-cativeiro-naregiao-metropolitana-de-belem-para-brasil/

Domingues, P. F. (2008). Sanidade animal no Brasil e o desenvolvimento agropecuário. Revista Internacional em Língua Portuguesa, 21, 93-105. http://aulp.org/publicacoes-rilp-21/

Franco, B. D. G. M., Landgraf, M., \& Destro, M. T. (2005). Microbiologia dos Alimentos. Atheneu.

Furtado, M. M. (2014). Artiodactyla - Tayassuidae e Suidae (Queixada, Cateto e Javali). In: Cubas, S. Z., Silva, R. C. J., \& Dias, C. L. J. (2nd ed.), tratado de animais selvagens: Medicina veterinária (pp. 1037-1053). Rocca.

Gill, C. O. (2007). Microbiological conditions of meats from large game animals and birds. Meat Science, 77 (2), 149-160. 10.1016/j.meatsci.2007.03.007.

International Commission on Microbiological Specifications for Food Staff (ICMSF) (2002). Microrganisms in Foods 7: Microbiological Testing in Food Safety Management. Kluwer Academic/Plenum Publishers.

International Organization for Standardization 6888-1 (ISO 6888-1). (1999). Microbiology of food and animal feeding stuffs - Horizontal method for the enumeration of coagulase-positive staphylococci (Staphylococcus aureus and other species). https://www.iso.org/standard/64947.html

Kornacki, J. L., Gurtler, J. B., \& Stawick, B. A. (2015). Enterobacteriaceae, coliforms, and Escherichia coli as quality and safety indicators. In: Salfinger, Y., \& Tortorello, M. L. (5th ed), Compendium of Methods for the Microbiological Examination of Foods (pp. 103-120). American Public Health Association.

Lamaita, H. C., Cerqueira, M. M. O. P., Carmo, L. S., Santos, D. A., Penna, C. F. A. M., \& Souza, M. R. (2005). Contagem de Staphylococcus sp. e detecção de enterotoxinas estafilocócicas e toxina da síndrome do choque tóxico em amostras de leite cru refrigerado. Arquivo Brasileiro de Medicina Veterinária e Zootecnia, 57 (5), 702-709. 10.1590/s0102-09352005000500017

Martins, L. L., Santos, I. F., Franco, R. M., Oliveira, L. A. T., \& Bezz, J. (2008). Avaliação do perfil bacteriológico de salsichas tipo "hot dog" comercializadas em embalagens a vácuo e a granel em supermercados dos municípios Rio de Janeiro e Niterói, RJ/Brasil. Revista do Instituto Adolfo Lutz, 67 (3), 215-220. https://periodicos.saude.sp.gov.br/index.php/RIAL/article/view/32768

Ministério da Agricultura, Pecuária e Abastecimento. (2017). Anuário dos programas de controle de alimentos de origem animal do DIPOA. http://www.agricultura.gov.br/assuntos/inspecao/produtos-animal/arquivos-publicacoes-dipoa/anuario-dipoa-v3/view/

Ministério da Agricultura, Pecuária e Abastecimento. (2018). Instrução Normativa n59, de 19 de dezembro de 2018. http://www.in.gov.br/materia//asset_publisher/Kujrw0TZC2Mb/content/id/56640378/do1-2018-12-24-instrucao-normativa-n-59-de-19-de-dezembro-de-2018-56640212/

Moraes, T. P., \& Timm, C. D. (2019). Importância dos animais silvestres como potenciais carreadores de patógenos alimentares. Medicina Veterinária (UFRPE), 13 (2), 143-151. 10.26605/medvet-v13n2-3036 
Research, Society and Development, v. 10, n. 5, e22010514772, 2021

(CC BY 4.0) | ISSN 2525-3409 | DOI: http://dx.doi.org/10.33448/rsd-v10i5.14772

Moreira, J. R., \& Macdonald, D. W. (1997). Técnicas de manejo de capivaras e outros grandes Roedores na Amazônia. In: Valladares-Pádua, C., \& Bodmer, R. E. Manejo e Conservação de vida Silvestre no Brasil (pp. 186-213). Sociedade Civil Mamirauá.

Nogueira, S. L. G., Filho, \& Nogueira, S. S. C. (2000). Criação comercial de animais silvestres: Produção e comercialização da carne e de subprodutos na região Sudeste do Brasil. Revista Econômica do Nordeste, 31 (2), 188-195. https://www.researchgate.net/publication/237364649_Criacao_Comerc ial_de_Animais_Silvestres_Producao_e_Comercializacao_da_Carne_e_de_Subprodutos_na_Regiao_Sudeste_do_Brasil

Oliveira, A. B. A., Paula, C. M. D., Capalonga, R., Cardoso, M. R. I., \& Tondo, E. C. (2010). Doenças transmitidas por alimentos, principais agentes etiológicos e aspectos gerais: uma revisão. Hospital de Clínicas de Porto Alegre, 30 (3), 279-285. https://seer.ufrgs.br/hcpa/article/view/16422

Parry, C. M. (2003). Antimicrobial drug resistance in Salmonella enterica. Current Opinion in Infectious Disease, 16 (5), 467-472. 10.1097/00001432200310000-00014

Quintiliano, C. R., Santos, T. A., Paulino, T. S. T., Schattan, R. B., Gollücke, A. P. B., \& Boitago, A. P. (2008). Avaliação das condições higiêncio-sanitárias em restaurantes, com aplicação de ficha de inspeção baseada na Legislação Federal, RDC, 216/2004. Revista Higiene Alimentar, 22 (160), 25-30.://www.bvsvet.org.br/vetindex/periodicos/higiene-alimentar/22-(2008)-160/avaliacao-das-condicoes-higienico-sanitarias-em-restaurantes-com-aplic/

Salfinger, Y., \& Tortorello, M. L. (5th ed.) (2015). Compendium of Methods for the Microbiological Examination of Foods (pp. 13-25). American Public Health Association.

Salvatori, R. U., Bessa, M. C., \& Cardoso, M. R. I. (2003). Qualidade sanitária de embutidos coletados no mercado público central de Porto Alegre- RS Ciência Rural, 33 (4), 771-773. 10.1590/S0103-84782003000400031

Santos, D. A., Amaral, G. V., Sartori, F., \& Simas, J. V. (2021). A importância das condições higiênico-sanitárias em abatedouros: Uma revisão de literatura. Research, Society and Development, 10 (1), e22610111455. 11455

Sarkis, F. (2002). Avaliação das condições microbiológicas de carnes de animais silvestres no município de São Paulo. 70f. Dissertação (Mestrado em Ciências) - Universidade de São Paulo.

Silva, N., Junqueira, V. C. A., Silveira, N. F. A., Taniwaki, M. H., Gomes, R. A. R., \& Okazaki, M. M. (2017). Manual de métodos de análise microbiológica de alimento e água. (5th.ed). Edgard Blucher Ltda.

Spolaore, A. J. G. (2007). Prevalência de Salmonella sp. em linfonodos mesentéricos de suínos abatidos na região oeste do Paraná e potencial de disseminação em bandejas, facas, e luvas de manipuladores durante a inspeção post-mortem. 59f. Dissertação (Mestrado em Ciências Agrárias) Universidade Federal do Paraná.

Taylor, T. M., Sofos, J. N., Bodnaruk, P., \& Acuff, G. R. (2015). Sampling plans, sample collection, shipment, and preparation for analysis. In: Salfinger, Y., \& Tortorello, M. L. (5th ed). Compendium of Methods for the Microbiological Examination of Foods, (pp. 13-25). American Public Health Association.

Tergney, A., \& Bolton, D. J. (2006). Validation studies on an online monitoring system for reducing faecal and microbial contamination on beef carcasses. Food Control, 17 (5), 378-382. 10.1016/j.foodcont.2005.01.004

World Health Organization (2019). Food safety. https://www.who.int/health-topics/food-safety/ 